\title{
Seasonal changes in fish abundance, biomass and species richness in the littoral zone of a large European lake, Lake Constance, Germany
}

\author{
P. Fischer and R. Eckmann ${ }^{1}$
}

With 5 figures and 4 tables in the text

\begin{abstract}
Seasonal changes in the abundance. biomass and species richness of fish in the littoral zone of Lake Constance were examined. Electric fishing was conducled in three depth strata at six dilferent sampling sites within the littoral zone from November 1991 to Februar 1993 during daytime. Minimal abundance and biomass values were observed in February with $3.9(\mathrm{SD} \pm 4.2)$ ind $10(0) \mathrm{m}^{-2}$ and $12.7(\mathrm{SD} \pm 1.3 .8)$ g-wel $100 \mathrm{~m}$-2. Maximal abundance values were observed in August with 119.5 (SD \pm 88.5 ) ind $100 \mathrm{~m} \div$. maximal biomass values in May with 903.9 ( $\mathrm{SD} \pm 1942.6$ ) g-wet $100 \mathrm{~m}^{2}$. The influence of individual habital variables on the littoral fish communily was examined by canonical correlation analysis. Seasonal changes in total fish abundance. biomass and species richness were mainly explained by seasonal changes in water temperalure followed hy lake level. For the individual species. different substrate characteristics such as sediment type or the amount of large stones lying on the bottom providing shelter werc also found to he important. However. these variables often influence fish abundance and hiomass only within a range that is predefined by water temperature. Different palterns were found for the two benthic species, burbot (Lotal lota) and stone loach (Noemacheilus barbatulus). The distribution of both species was mainly correlated with the availability of gravel substrate and shelter and mostly independent of littoral water temperature. Burbot larger than $>5 \mathrm{~cm}$ TL emigrated from the littoral into deeper adjacent areas during summer when water temperature increased above a certain threshold, indicating an upper thermal threshold for this cold stenothermal species.
\end{abstract}

\section{Introduction}

Seasonal changes in abundance. biomass and species richness are characteristic for the littoral fish communities in many temperate lakes (NüMANN 1939. Benson \& Magnuson 1992. Pierce el al. 1994). Most freshwater fish. in-

'Authors' address: Limnologisches Institut - Universitäı Konstanz. Mainaustr. 212. 78464 Konstanz. Germany. 
cluding those regarded as typically pelagic, often use littoral resource- tempurarily at certain times of the year either for spawning. larval and jur enile de velopment or as feeding habitat (WERner et al. 1977. SchlosSER 1982. Mi RNER et al. 1983. COPP 1992, GAFNY et al. 1992). Juvenile fish in particular ue the littoral zone during the summer months to accelerate their growth rates in the warm, highly productive shallow areals (AI LEN 1982. CFRRI \& FRASI:R 1983. BarAs 1995, Fischer \& ECKM.ANi 1997) and the generally higher structural complexity of littoral habitats additionally increases protection from larger piscivorous predators (CROWIDER \& COOPER 1982. WERNER ct al. 1983. SChlosser 1987. Savino \& Sitin 1989).

In contrast to most small, shallow lakes where many lish use littoral resources over the entire seasonal cycle. in large. deep lakes lish often undertake substantial seasonal migrations between shallow littoral habitats in summer and pelagic or profundal habitats in winter. In Lake Convance. a total of 33 fish species are known from the entire lake. Serenteen specie are regarded as obligate littoral dwellers and 15 species are assumed to une littoral resources at least during a short period at some season (BtRc \& BI $\backslash \mathrm{k}$ 1990). However. except for an early qualitative assessment of the littoral fish community by Nümann (1939), no data are available since then about caasonal migrations and habitat use by the littoral fish species of the vecond larger pre-alpine lake in Europe. We know that Lake Constance has undergone a dramatic change in nutrient levels. from oligotrophic to eutrophic and hach to mesotrophic. during the last 30 years (GAEDKE \& SCHWEIZER 1993) with trong effects on the fish (Nümann 1973, Hartmann \& Nümann 1977. Röse h \& So huld). in press). However, littoral fish communities were mostly excluded from these analyses so that our knowledge about seasonal dynamics of the littoral fish community is lar from satisfactory. Fischer \& E( K.11+ 11997 , recently presented a study concerning spatial distribution patterne in the littoral fis h community of Lake Constance and showed a high temporal and upatial diversity in littoral fish species during phases of greatest abundances and biomasses for individual species. In this paper, we focus on seasonal changes in the littoral fish community of Lake Constance over the entire seasonal cycle " ith respect to 1) seasonal changes in fish abundance. biomass and pecies richness and 2 ) key halbitat factors influencing the seasonal changes of the littoral fish assemblage in Lake Constance.

\section{Material and methods}

\section{Study site}

Lake Constance (upper lake) has a toral surface area of $500 \mathrm{hm}^{2}$. a mean depth of $95 \mathrm{~m}$ (max. $254 \mathrm{~m}$ ) and a shoreline length of $186 \mathrm{~km}$. The littoral zone. according to WETzFI 


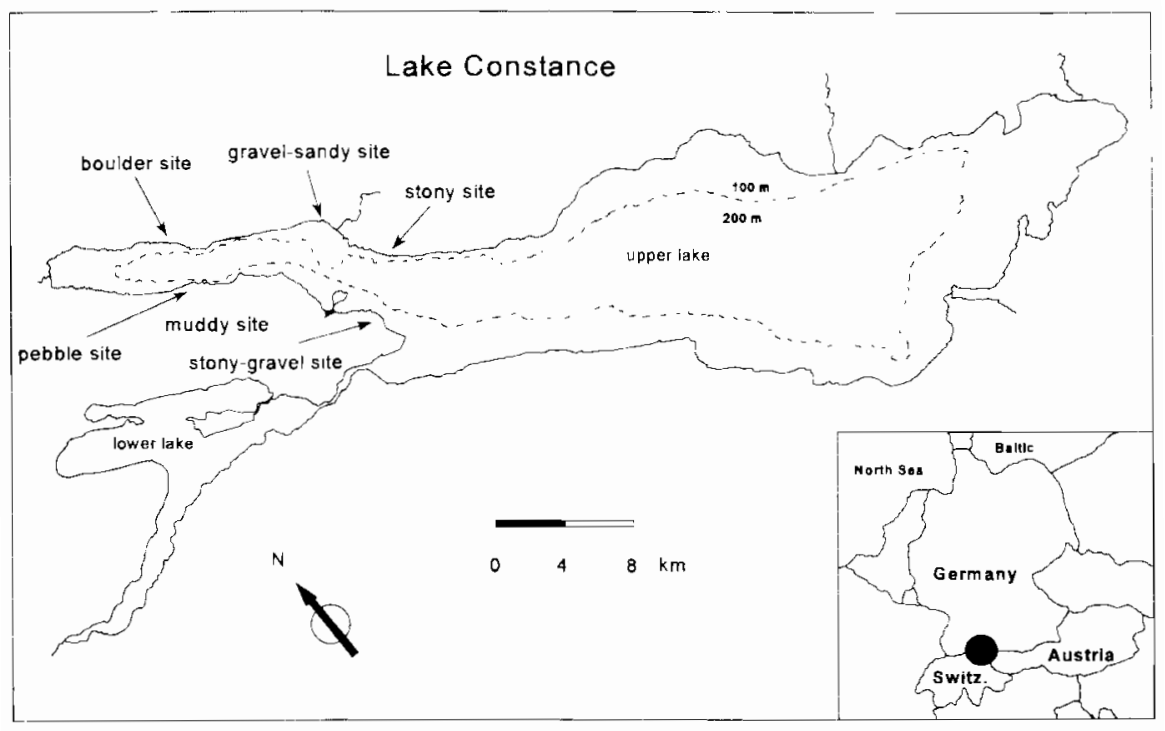

Fig. 1. Map of Lake Constance. The six sampling sites are marked with black arrows.

(1983) and JoRGitNSF:N (1990) the shallow-water zone from the shoreline to the lower boundary of the submerged aquatic vegetation. extends to a water depth of about $5 \mathrm{~m}$ below high lake level conditions in sunmer. Six sampling sites were selected in the north-western part of the lake (Fig. 1). These sites ranged from extended littoral areas with low slopes and muddy sediments to narrow helf-like areas with gravel sediment and a pronounced drop at approximately $20 \mathrm{~m}$ from the shoreline. For a detailed de scription of the individual sampling sites see Fisc IILR \& EcKunvN (1997).

\section{Field methods}

Electric fishing was used for sampling from November 1991 until February 1993 during daytime. All six sites were sampled twice each month from April to December and monthly from January to March with three different depth strata (shallow: $0-50 \mathrm{~cm}$. intermediatc: $50-150 \mathrm{~cm}$, deep: $150-300 \mathrm{~cm}$ ). For sampling the shallow and intermediale strata. the stationary generator part of the electric fishing device was placed on the beach and the anode and cathode were connected with $100 \mathrm{~m}$ iong cables. Each stratum was sampled with four replicate enclosure nets $(4.0 \mathrm{~mm}$ bar mesh. $1 \mathrm{~m}$ height in the stratum shallow and $2 \mathrm{~m}$ height in the stratum intermediate) to completely enclose arcas of about $50 \mathrm{~m}^{2}$. We exposed the nets fully raised as carefully as possible. with only one or two persons in the water. When an escape reaction was observed in the fish while deploying the nets, the procedure was stopped and another area in the same habitat and same depth stratum was selected an an alternative sampling site. Each area enclosed with nets was sampled four times at intervals of 15 minutes ( 15 min sampling/15 min rest). In the deep stratum enclosure nets did not provide satisfactory data in preliminary samplings because of temporarily dense macrophyte vegetation. We 
sampled this stratum without enclosure nets from a boal for the same time as we sampled in the shallower strata. This diflerence in sampling procedure resulted in larger sampling areas in the deep stratum which were. however. sampled less intensily.

All catches were anaesthetized immediately after capture with 1,1.1-Trichloro-2methyl-2-propanol (Chlorobutanol) and separated by day. sampling site and depth strata. Small fish were preserved in 5\% formaldehyde, larger species such as European eel Anguilla anguilla and pike Esox lucius were measured (total Jength TL and standard length SL) to the nearest millimeter and released. The weight of these individuals was back-calculated using length-weight relationships from previous data and from RADKL (1993). In the laboratory, all preserved fish were identificd to species. measured (TL and SL. to the nearest millimeter) and weighed (wet) to the nearest $0.01 \mathrm{~g}$.

\section{Habitat measurements}

The measuring procedures for the habitat variables are shown in Table 1. Water temperature and lake level varied significantly over the seasons (Fig. 2). Because of the pronounced water level fluctuations, caused by rainfall and meltwater runoff from the Alps, habitat structure within the littoral zone also varied seasonally. Therefore, we measured all habitat variables (Table 1 ) on each sampling occasion. For the variables substrate coverage (pereentage of sediment covered by larger stones). mean stone size and stone size range we made one initial detailed measurement. using SCUBA. at each of the six sampling sites. Because of the seasonal changes in submerged aquatic vegetation composition and density, all three SAV variables (Table I) were measured by SCUBA diving once a month during the SAV growing season. We measured each habitat variable in five depth strata ( $0105 \mathrm{~m}$ water depth) with five replicates in each stratum (four in the case of SAV). For a detailed deseription of the measuring procedure of the individual habital variables see FISCHFR \& EC KMANN (1997). Based on these references, visual censuses of the individual habitat and SAV parameters were performed

Table 1. Habitat variables used to analyse fish abundance, biomass and distribution differences. Measuring procedure visual* is explained in the text.

\begin{tabular}{|c|c|}
\hline habitat variables & measuring procedure and scales \\
\hline water temperature & 0,100 and $300 \mathrm{~cm}$ water depth, measured to $0.1{ }^{\circ} \mathrm{C}$ \\
\hline lake level & cm above lake level 0 (water depth gauge Konstanz) \\
\hline depth strata & $\begin{array}{l}\text { shallow }(0-50 \mathrm{~cm}) \text {, intermediate }(50-150 \mathrm{~cm}) \text {, deep } \\
(150-300 \mathrm{~cm})\end{array}$ \\
\hline substrate & mud $(0)$-gravel $(10)$, visual $*$ \\
\hline sub: & $\begin{array}{l}\text { percent area of substrate covered with larger stones, } \\
\text { visual*: }\end{array}$ \\
\hline mean stone size & diameter $(\mathrm{cm})$, visual ${ }^{*}$ \\
\hline stone siz & 11), visual* \\
\hline SAV Potamogeton pectinatus & density (live level scale). visual:" \\
\hline SAV Potamogeton perfoliatus & density (five level scale), visual:" \\
\hline SAV Chara spp. & density (five level scale), visual ${ }^{*}$ \\
\hline
\end{tabular}




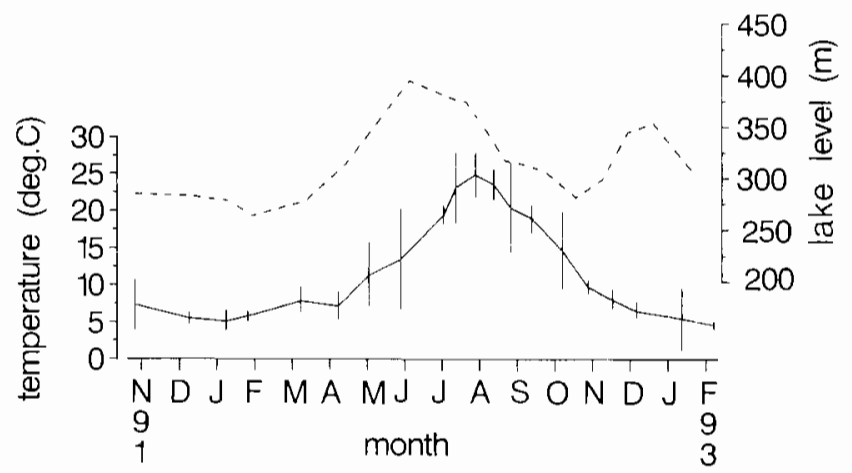

Fig. 2. Mean littoral water temperature and lake level in Lahe Constance during the sampling period, November 1991 to Februal 1993.

for each sampling site and depth stratum on all subscquent sampling occasions. All habitat paramelers were assessed by the same person over the entirc sampling period.

\section{Statistical analyses}

Preliminary statistical analyses showed non-normal distribution in most of the untransformed. as well as log and square root transformed. catch data. We therefore ranktranstormed abundance and biomass data across scason and applied ANOVA - Duncan's Multiple Range comparisons of Means (SAS 1988) 10 test differences in littoral lish abundance and biomass among months. We used canonical correlation andyes (CCA), (HoItLling 1936) in our evaluation of relationships between fish and habitat across season. To reduce the problem of autocorrelation in the input data set in the CCA (BORIz 1985), we used the correlation coeflicient $r$ of individual habitat varialbles (temperature. lake level, depth strata. substrale type, substrate coverage, mean stone size, stone size range, littoral width, SAV (Potcinogeton pectinatus), SAV (Potcmogeton perfoliatus). SAV (Characea)) with the first canonical axis of the criterion variables (abundance. biomass. species richness) as recommended by SAS (1988). These values range from -1101 and can be compared to each other by their absolute numerical value. Statistical procedures included SAS-ANOVA lor abundance and biomass differences among month and SAS-CANCORR for the analysis of relationships among individual species and habitat variables (SAS 1988).

\section{Results}

Abundance. biomass and species richness of fish in the littoral integrated over all sampling sites and depth strata varied significantly over the year (Fig. 3). Lowest abundance and biomass values were observed duting February with 3.9 $(\mathrm{SD} \pm 4.2)$ ind $\cdot 100 \mathrm{~m}^{2}$ and $12.7(\mathrm{SD} \pm 13.8) \mathrm{g}-\mathrm{wet} \cdot 100 \mathrm{~m}^{-2}$. Highest abundance values were recorded in August with $119.5(\mathrm{SD} \pm 88.5)$ ind $\cdot 100 \mathrm{~m}^{2}$. 

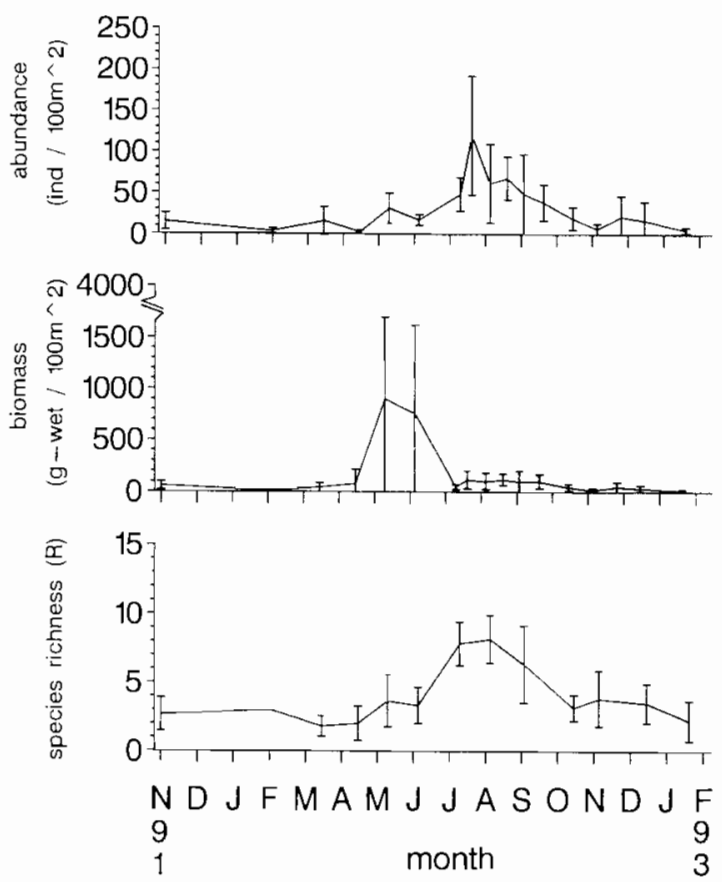

Fig. 3. Abundance, biomass and species richness of littoral fish species in Lakc Constance. Mean values are plotted, with standard deviations. integrated over all sampling sites and depth strata from November 91 to Februar 93.

highest biomass values in May with 903.9 ( $\mathrm{SD} \pm 1942.6) \mathrm{g}$-wet $100 \mathrm{~m}{ }^{2}$. Species richness also varied signilicantly across seasons (Fig. 3. lower graph). With an average value during December to June of $\mathrm{R}=2.8$ ( $\mathrm{SD} \pm 1.6$ ). species richness was significantly lower compared to the months of July and August $(\mathrm{R}=8.0(\mathrm{SD} \pm 1.9), \mathrm{p}<0.001)$.

The canonical correlation nr. I among the multivariate dependent fish variables (abundance. biomass and species richness) and the multivariate independent habitat variables showed a highly significant correlation $(\mathrm{p}<0.000)$ ) of the two datasets across season (Table 2). The first canonical correlation was 0.67 and explained $63 \%$ of the variance of the two datasets. Temperature and lake level reached the highest correlations to the first canonical axis of the fish variables $(r=+0.59$ and +0.48$)$. None of the other habitat variables reached correlations higher than $r=+0.19$. This indicates that changes in water temperature. followed by lake level. are the two most important factors that inlluence lotal lish abundance, biomass and species richness in the littoral zone of Lake Constance through the seasons.

Canonical correlation nr. II (the remaining correlation between the two data sets after compensating for the most prominent habitat variables in canon- 
Table 2. Canonical correlation for total fish abundance, biomass and specics richness $(\mathrm{R})$ in the littoral zone of Lake Constance. Corrclation coefficients $r$ of the multivariate independent variables (predictor) and the lirst canonical axis of the multivariate dependant variables (criterion) are shown. Further explanations in text.

\begin{tabular}{|c|c|c|c|c|c|}
\hline \multirow{3}{*}{$\begin{array}{l}\text { Input data } \\
\text { ranked over: } \\
\text { Canonical correlation nr. }\end{array}$} & \multirow{2}{*}{\multicolumn{2}{|c|}{$\begin{array}{l}\text { entire } \\
\text { season }\end{array}$}} & \multirow{3}{*}{$\begin{array}{l}\text { October } \\
\text { to April } \\
\text { I. }\end{array}$} & & \\
\hline & & & & \multicolumn{2}{|c|}{$\begin{array}{c}\text { May to } \\
\text { September }\end{array}$} \\
\hline & I. & II. & & I. & II. \\
\hline$r^{2}$ & 0.67 & 0.49 & 0.6 .5 & 0.65 & 0.49 \\
\hline $\mathrm{pr}>\mathrm{F}$ & $<0.000)$ & $<0.0000 \mathrm{l}$ & $<0.001$ & $<0.0001$ & $<0.001$ \\
\hline Variance explained: & $6.3 \%$ & $28 \%$ & $71 \%$ & $62 \%$ & $18 \%$ \\
\hline \multicolumn{6}{|l|}{ criterion: } \\
\hline abundance & 0.97 & 0.13 & 0.55 & 0.62 & 0.75 \\
\hline biomass & 0.71 & 0.68 & 0.75 & -0.08 & 0.99 \\
\hline species richness ( $R$ ) & $(1.60$ & 0.24 & 0.60 & 0.46 & 0.29 \\
\hline \multicolumn{6}{|l|}{ prediclor: } \\
\hline temperature & 0.59 & 0.08 & 0.14 & 0.42 & 0.00 \\
\hline lake level & 0.48 & 0.05 & -0.25 & 0.10 & 0.27 \\
\hline depth strata & 0.02 & $-0.0) 2$ & 0.12 & -0.07 & -0.29 \\
\hline substrate type & $0.0+$ & 0.31 & $0 .+7$ & 0.15 & 0.20 \\
\hline substrate coverage & $-0.1) 2$ & 0.30 & 0.29 & 0.21 & 0.33 \\
\hline mean stone size & 0.02 & 0.20 & 0.49 & 0.08 & $0.2 !$ \\
\hline stone vize range & 0.02 & 0.02 & 0.43 & 0.06 & 0.01 \\
\hline SAV (Chara spp.) & 0.13 & 0.01 & 0.00 & 0.01 & -0.13 \\
\hline SAV $(P$. pectinatus $)$ & 0.19 & $-0.1+$ & 0.00 & 0.08 & -0.11 \\
\hline SAV (P. perfoliatus) & 0.09 & -0.15 & 0.00 & -0.02 & -0.16 \\
\hline
\end{tabular}

ical correlation $\mathrm{nr}$. I) reached an $\mathrm{r}^{2}$ value of 0.19 (Table 2 ). Then, the variables substrate type and substrate coverage reached the highest correlations with $r=$ +0.31 and $r=+0.30$. Thus, these two variables have the strongest influence on the distribution of fish species within the littoral zone after the effects of seasonal changes in water temperature and lake level have been removed.

Between-month comparison (ANOVA-Duncan grouping, SAS 1988) revealed two significantly different phases with respect to total fish abundance and biomass across season (Table 3). In the spring-summer period from May to September. abundance values were significantly higher $(p<0.001)$ compared to the autumn-winter period from October to April. For total fish biomass. differences between the two periods were even more pronounced. with minimal values of $35.0 \mathrm{~g}$-wet $100 \mathrm{~m}^{-2}$ in January and maximal values up to $5701 \mathrm{~g}$-wet $100 \mathrm{~m}^{-2}$ in June. However, significance patterns for biomass were less continuous across the seasons. Significantly higher values were observed only in May and June and in August and September (Table 3). Separate CCAs for the autumn-winter and spring-summer periods revealed different habitat variables to be important for the littoral fish community during these two seasons (Table 2). In the autumn-winter period (October to April) when fish abun- 
Table 3. $\Lambda$ NOVA-Duncan multiple range tes for nean abundiance and himals values in the littoral zone of Lake Constance per month. Mean values whth the ame letter are not signilicantly different wilh $p<0.001$.

\begin{tabular}{|c|c|c|c|c|c|c|c|c|c|c|c|}
\hline \multirow[t]{2}{*}{ month } & \multicolumn{6}{|c|}{ abundance (ind $100 \mathrm{~m}^{-}$) } & \multicolumn{5}{|c|}{ biomals } \\
\hline & $\begin{array}{l}\text { mean abundance } \\
\text { and atl. crror }\end{array}$ & & & $\begin{array}{l}\text { ncan-an } \\
\text { upin }\end{array}$ & & & $\begin{array}{l}\text { mean biomas } \\
\text { and sid. croror }\end{array}$ & & & & \\
\hline Jinuary & $5.1(1.0)$ & & & & & $\mathrm{F}$ & $35.0(6.5)$ & & & & \\
\hline February & $1.7(2.2)$ & & & & & $\mathrm{F}$ & $126.9(86.2)$ & $\mathrm{A}$ & $\mathrm{B}$ & (c & \\
\hline March & $16.1 \quad(8.3)$ & & & & & $\mathrm{E}$ & $82.5(.32 .9)$ & & $B$ & $\mathrm{C}$ & D \\
\hline April & $3.5(0.9)$ & & & & & $\mathrm{E}$ & $82.3(52.9)$ & & & $\mathrm{C}$ & D \\
\hline Mily & $31.3(9.1)$ & A & B & $\mathrm{C}$ & D & & $3712.2(.3158)$ & A & & & \\
\hline Itın & $17 .+(3.2)$ & & B & $\mathrm{C}$ & D & & $5701.7(5435)$ & A & & & \\
\hline July & $83.9(20.9)$ & A & & & & & $115 .+(22.9)$ & A & $\mathrm{B}$ & $\mathrm{C}$ & D \\
\hline Augu: & $6(12$ & A & B & & & & $262.2(76.4)$ & A & B & & \\
\hline Sep & $+3.1(12.7)$ & A & $\mathrm{B}$ & $\mathrm{C}$ & & & $182.0(57.4)$ & A & $\mathrm{B}$ & $\mathrm{C}$ & \\
\hline 0 & $20.4(7.7)$ & & & $\mathrm{C}$ & D & & $66.9(20.9)$ & & B & & 1) \\
\hline & $16.8 \quad 15$. & & & C & D) & E & $92.3(28.2)$ & & $\mathrm{B}$ & $\mathrm{C}$ & D \\
\hline December & $19.2(12.5)$ & & & $\mathrm{C}$ & D & $E$ & $189.8(150.4)$ & & B & $\mathrm{C}$ & D \\
\hline
\end{tabular}

dance and biomass values were al a comparatively lou level. the habilat variables mean stone size. substrate type and stone size range reached the highest correlations $(r=+0.49,+0.47$ and +0.43$)$ to the canonical axis of the fish variables. During this lime of the year, water temperature and lake level ranked lower with $r=+0.14$ and $r=-0.25$. This suggests that. during the months of low water temperature and low lake level. substrate characteristics are the most important habitat variables influencing fish distribution in the littoral zone of Lake Constance. During this time of the year burbot (Lota lota) and stone loach (Noemacheilus barbatulus) together dominated the littoral fish community comprising up to $87.2 \%$ of the total fish abundance (Fig. 4). Species specific CCA (Table 4) showed, that abundances and biomass of burbot and stone loach were strongly positively correlated to substrate coverage with $r=+0.61$ and $r=+0.59$. In both species, the variable depth strata ranked second $(r=-0.44$ and -0.55$)$. The variable water temperature however only ranked low with $r=+0.15$ and +0.16 . This shows. that in contrast to the analysis for lolal fish abundance and biomass across season, changes in littoral water temperature do not have a strong elfect on burbot and stone loach distribution.

Abundance and biomass of these two species are mainly dependent on the substrate characteristics within the littoral zone and increase with increasing substrate coverage and therefore with the availability of shelter in the shallow areas. Only lor burbol was the second canonical correlation significant $(\mathrm{p}<0.000)$. Table 4). It revealed a high but negative correlation of the variable water temperature $\left(r^{\prime}=-0.27\right)$. This shows that increasing water temperalture 
dominance $(\%)$

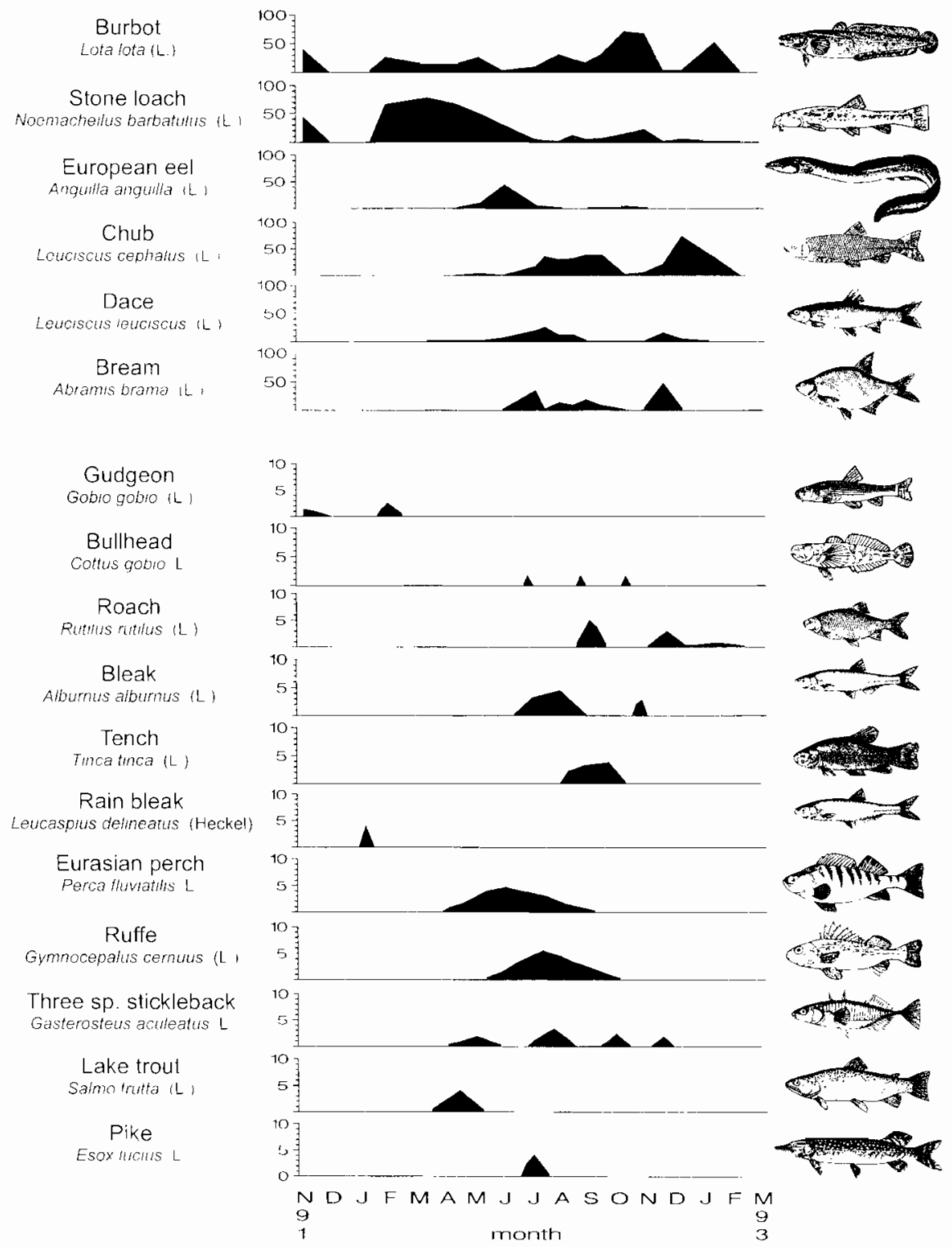

Fig. 4. Species dominance (percent abundance of total catch) of fish species in the littoral zone of lake Constance. Plotted are mean values integrated over all sampling sites and depth strata from November 91 to Fehruar 93. Please note different scales on dominance axis.

has a negative elfect on burbot and acts as suppresser of burbot abundance and bionass in the littoral zone. 
Table 4. Canonical correlation for fish species in the littoral zone of Lake Constance. Correlation coefficients $r$ of the multivariate independent variables (predictor) and the lirst canonical axis of the multivariate dependant variables (criterion) are shwon. Input data are ranked over the entire sampling period. Further explanations in text.

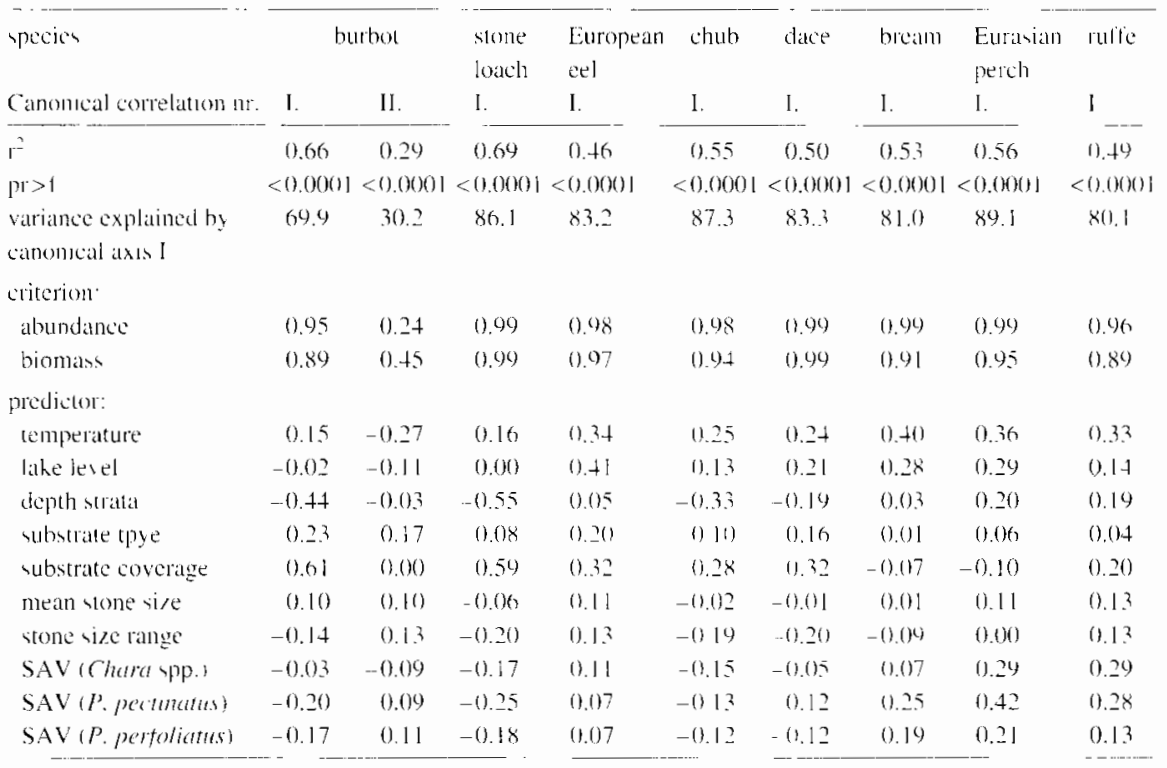

During the spring-summer period (May to September), total fish abundance, biomass and species richness in the littoral zone increased significantly (Fig. 3). The CCA for total fish abundance, biomass and species richness (Table 2 ) now revealed a high correlation with the variable water temperature ( $\mathrm{r}=$ +0.42 ) and comparatively low values for all other habitat variables. Changes in water temperature therefore seem to be the main factor influencing fish abundance and biomass in the littoral zone of Lake Constance during the spring and summer months. A high significance level of canonical correlation no. II $(p<0.001)$ during this period of the year allowed a detailed evaluation of the data after compensation for the strong effect of water temperature. High values of the variables substrate coverage $(r=+0.33)$, lake level $(r=+0.27)$ and depth strata $(r=-0.29)$ then showed that these variables also influence the distribution of the littoral fish community but mainly within a range first determined by water temperature.

During this time of the year, European eels (Anguilla anguilla) and the three cyprinid species chub (Leuciscus cephalus), dace (Leucise'us leuciscus) and bream (Abramis brama) successively dominated the littoral fish community (Fig. 4). In addition, the two percids, ruffe (Gymnocephalus cernuus) and Eurasian perch (Perca fluviatilis), were also caught over a longer period of 
time but they never dominated the catches. For five of the six species temporarily present in greater abundances in the catches. the variable water temperature ranked first or second in the CCA (Table 4). However. after water temperature, different habitat variables were important for the individual species. In chub. the variable depth strata ranked first $(r=-0.33)$, in dace the variable substrate coverage $(r=+0.32)$ was first. This suggests that in both species. abundance and biomass increase towards areas of high substrate coverage in the shallow areas. In bream. the variable lake level ranked second with $\mathrm{r}=$ +0.28 . The variable SAV ( $P$. perfolicitus) also ranked higher with a positive value of $r=+0.25$. This shows that - in contrast to chub and dace - bream abundance is positively influeneed by dense aggregations of SAV. The two percid species Eurasian perch and ruffe showed similar habitat preferences to those of bream except for the species composition of SAV. Besides water temperature, perch abundance and biomass showed highest correlations to the variable SAV ( $P$. pectinutus) $(\mathrm{r}=+0.42)$. In ruffe, higher correlations were observed for SAV (Chara spp.) ( $\mathrm{r}=+0.29)$. This reflects the fact that, as in most other species. abundance and biomass values in ruffe and perch increase with increasing water temperature. but perch abundance strongly increases with the presence of dense Potamogeton pectinatus, ruffe abundance with the presence of Chara spp. or Potamogeton pectinatus.

\section{Discussion}

To address the problem of estimating population parameters when relying on a single gear or sampling method (EgGress et al. 1978), we compared our electric fishing data with trammel net catches conducted in parallel (FISCHER \& EcKMANN 1997) and also with $24 \mathrm{~h}$ samplings with monofilament gill nets of different mesh sizes $(6 \mathrm{~mm}, 12 \mathrm{~mm}$ and $45 \mathrm{~mm}$ ), (FIscher, unpubl. data). We found similar seasonal changes in depth and species distribution with all three sampling methods but missed some species in the different gears. This was especially true for the percid species Eurasian perch and ruffe. Both species ranked low in our electric fishing catches but were most abundant in our tram$\mathrm{mel}$ net catches and the $24 \mathrm{~h}$ fishery. Furthermore, coregonid larvae (Coregonus lavaretus) were observed in great abundance in the very shallow areas for a short time during the sampling period, but they never occurred in our catches. We therefore assume that our electric fishing data underestimate total abundance and biomass of Eurasian perch and ruffe as well as of coregonid larvae but provide reliable estimates for most other species.

Our results show that water temperature, followed by lake level are the two primary habitat variables with respect to seasonal changes of total fish abundance, biomass and species richness in the littoral zone of Lake Constance. 
The importance of water temperature for juvenile fish is well documented (GiBSON 1994). Higher water temperatures increase growth rates (BREI 1979). reduce predation risk (VINCE et al. 1976. WERNIR et al. 198.3) and increase foraging success (PIICHER \& HARI 1982). Increasing water temperatures also affect littoral fish species indirectly by increasing growth of SAV and hence the structural complexity of the habitat (Heck et al. 1984. ORTH et al. 1984. Savino \& Stein 1989). GaFny et al. (1992). however. showed that stochastic water level fluctuations may also be of significant importance for littoral fish communities and. in some cases. may overrule the strong influence of water temperature. Pronounced water level lluctuations may separate or unify difterent parts of lake basins (MONRoE \& LARKIN 195()) or change the amount of littoral areas available (GEI_WICK \& MATTHFws 1990)). In this way, some unique habitat types may become available for lish only when the lake level increases above a certain level (GasITH \& GAFNy 1990).

Such a situation was observed in Lake Constance in May and December 92. With increasing water level in May 92. an area of big cobbles $(30-50 \mathrm{~cm})$ at the boulder site became inundated within a few days. Mean fish biomass al this site increased from $<400$ up 1040.000$) \mathrm{g}$-wet $\cdot 100 \mathrm{~m}^{-2}$ in less than four weeks. This increase was mainly due to large eels who used this specific habitat for shelter. Because the artificial shoreline reinforcement was unique to this sampling area. a similar biomass increase could not be observed at any other site. Nevertheless, because of a simultaneous increase in water temperature during that period of the year, we cannot separate the inlluence of increasing water level and water temperature and therefore are not able to identify the ultimate factor triggering the observed eel migration to the littoral zone. The effects of an increase in lake level without a simultaneous increase in water temperatures could, however, be studied in December 93. An unusually long period of warm weather in the Alps during November 93 elevated the lake level to almost summer values for a period of approximately 3 weeks (Fig. 2), while water temperatures remained almost constant at 5-8 C. During this period. mean lish abundance and biomass did not change significantly in most littoral areas. Also. at the boulder site no increase in eel abundanee or biomass was observed. Like Jones et al. (1966). Hest Hagen (1975) and Al i.en (1982). we therefore assume that water temperature is the most important factor that influences seasonal changes in total littoral fish abundance, biomass and species richness in Lake Constance by triggering migratory movements from and to the littoral zone. Lake level may be regarded only as the most important habitat variable that influences abundance and biomass distribution within the littoral zone. as long as water temperature is sulficiently high.

However, data for individual species show that this is not valid for all species. Juvenile burbot and stone loach were collected during the entire year in great abundance and biomass in the littoral zone. even in winter when water 


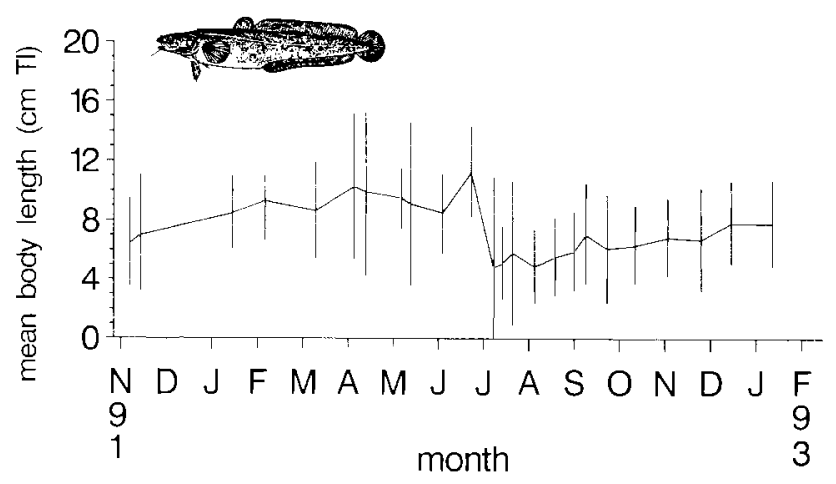

Fig. 5. Average body length of burbot (Lota lota) each month. Plotted are mean values. with standard deviations. integrated oner all sampling sites and depth strata.

temperature dropped to 0 C and ice cover was seen in the very shallow water. For these species. in the CCA substrate variables ranked higher than water temperature. indicating a strong preference for areas with a high percentage of stone coverage. The second canonical correlation even indicates a negative correlation between increasing water temperature and burbot biomass in the littoral zone. This negative relationship is mainly explained by the emigration of larger burbot out of the littoral zone during summer. In July, a sharp decline in mean body length occurs in burbot from an average of $11.4 \mathrm{~cm}$ TL at the end of June to about $4.8 \mathrm{~cm}$ TL in July (Fig. 5). At this time of year, the water level and most of the substrate variables in Lake Constance remained relatively constant but water temperature increased from an average of about 12 to more than 18 degree Celsius. Scott \& Crossmann (1973) reported a temperature optimum of 15.6 to 18.3 degree Celsius for burbot and NümanN (I939) and HARTMANN (1977) described adult burbot as typically cold stenothermal, living and spawning in greater water depth in Lake Constance. We therefore assume that the decrease in mean body length in juvenile burbot is directly related to the increasing water temperature in the littoral zone during June and July. In such a situation. the variable water temperature can also be regarded as the ultimate habitat variable by excluding especially larger individuals from the shallow littoral zone during the warmest summer month.

\section{Acknowledgements}

We thank A. Sulgir. M. Scimid, R. Radke. F. Imbrock. S. Häriel. M. Kahnert and M. Si FINHARD for helpful assistance in the field and laboratory work. U. ZIMmERMANN and E. JAHFI-BANKA helped a lot in preparing data and graphs as did M. WoL.1 with technical equipment. Valuable comments on the manuscript came from $H$. Kautsky. I. Bussmann and K. PÜt7. We especially want to thank two unknown reviewers for their valuable comments on the manuscript. This study was financed by 
the Ministry of Research and Technology ( $\mathrm{Nr} .0339385 \mathrm{~A}$ ). The responsibility for the content belongs to the authors. Additional financial and technical support was given by the LION Foundation University Konstan and the DFG Sonderforschungsbereich "Stoffhaushalı des Bodensees" (SFB 248).

\section{References}

AI.LEN. L. G. (1982): Seasonal abundance. composition, and productivity of the littoral fïsh assemblage in upper Newport Bay, California. - Fish. Bull. 80: 769-790.

BARAS. E. (1995): An improved electrofishing methodology for the assessment of habilat use by young-of-the-year fishes. - Arch. Hydrobiol. 134: 403-415.

Benson. B. J. \& MAgnusson. J. J. (1992): Spatial heterogeneily of littoral fish assemblages in lakes: relation to species diversity and habitat structure. - Can. J. Fish. Aqual. Sci. 49: $1493-1500$.

BERG, R. \& Bl.ANK. S. (1990): Die Fische in Baden-Württemberg. - Ministerium liü ländlichen Raum. Ernährung, Landwirtschaft und Forsten Baden-Württemberg, Stultgart.

Bortz. J. (1985): Lehrbuch der Stalistik: Für Sozialwissenschaftler. - Springer. Berlin/Heidelberg. New York.

BRETT. J. R. (1979): Environmental factors and growth. - In: HoAR. W. S.. RANDAL.L. D. J. \& Bret1. J. R. (eds.): Fish physiolog!. - Academic Press. New York. pp. $599-675$.

Cerri. R. D. \& Fraser. D. F. (1983): Predalion and rish in foraging mimnou a balaneing conflicling demands. - Amer. Nat. 121: 552-561.

Copp, G. H. (1992): Comparative microhabitat use of cyprinid lart ale and jueniles in a lotic floodplain channel. - Env. Biol. Fish. 33: $181-193$.

Crowder. L. B. \& Coopre, W. E. (1982): Habitat structural complevity and the interactions between blucgills and their prey. - Ecolog! 63: $1802-1813$.

Eggers. D. M.. Baraioo, N. W. Rickard. N. A.. Ni.son. R. E.. Wissmar. R. C.. Burgner. R. L. \& Devol. A. H. (1978): The lake Washington ecosystem: the perspective from the fish community production and rorage base. - Can. J. Fish. Aquat. Sci. 35: 1553-1571.

Fischer. P. \& ECKmann. R. (1997): Spatial distribution of litloral fish species in Lake Constance. Germany. - Arch. Hydrobiol. (in press).

GaгnкE, U. \& Schwi:1/t.k. A. (1993): The first decade of oligotrophicalion in Lake Constance. I. The response of phytoplankton biomass and cell size. - Oecol. 93: $268-275$.

GAFNy. S. GAstrh. A. \& Goren, M. (1992): Effect of water level flucluation on shore spawning of Mirogrex terresesanctae (Steinitz). (Cyprinidae) in Lake Kinnerct. Israel. - J. Fish. Biol. 41: 863-871.

Gasith, A. \& Gafny. S. (1990): Effects of water level fluctuations on the structure and function of the littoral zone. - In: Til.zer. M. M. \& SERruYA. C. (eds.): Large lakes: ecological structure and function. - Science-Tech Pub, Madison Wisconsin. pp. $156-173$.

Gelwick, F. P. \& MAtThews, W. J. (1990): Temporal and spatial patterns in littoralzone fish assemblages of a reservoir (Lake Texoma. Ohlahoma-Texas. USA). Environ. Biol. Fishes. 27: 107-120. 
Gibson. R. N. (1994): Impact of habitat quality and quantity on the recruitment of juvenile f7atfisher. - Neth. J. Sea Res. 32: 191-206.

Hartmanin. J. (1977): Die Trüsche (Lota lota) im eutrophicren Bodensee. - Arch. Hydrobiol. 80: 360-37-

Hartmann. J. \& NíuanN. W. (1977): Percids of Lake Constance: al lake undergoing cutrophication. - J. Fish. Res. Board Can. 34: 1670-1677.

HEck. K. L. Ir. \& THovisv. T. A. (1984): The nursery role of seagrass meadows in the upper and lower reaches of the Chesapeake Bay. - Estuarien 7: 70)-92.

HFs rH I6I. \. I. T. 119751 : Seasonal oceurrence and length variation in the sand goby. Pomatoschistus minumes (P+1 L.AS), in the shore zone of the inner Oslo Fjord. Nork. J Zool. 23: 235-242.

Holflidaci. H. (1936): Relalions of two sets of variables. - Biometrika 28: 321-377.

Jones. D. \& MII I.R. P. J. (1966): Seasonal migrations of the common goby. Ponatoschistum m(rop (KRo) I R). in Morecambe Bay and elsewere. - Hydrobiologica 27: $515-528$.

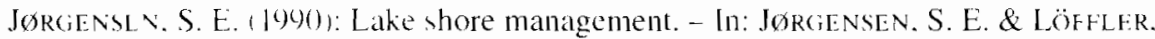
H. (eds.): Guideline of lake management, vol. 3. - Otsu, Shiga Japan. pp. 1-3.

MONROE. D. A. \& L IRKIN. P. A. (1950): The effects of changes to the neutral water level and water courue on wildlife. - Trans. British Columbia Nat. Resour. Conf. 3: $267-272$

NËMA N`. W. (1973): Versuch einer Begriindung für den Wandel in der qualitativen und quantitativen Zusimmensetzung des Fischbestandes in Bodensee während der letzten 60 Jahre und eine Bewertung der Besatzmal3nahmen. - Schweiz. Z. Hydro. 35: $206-238$.

- 19391: Lnteruchungen uiber die Biologic einiger Bodenseefische in der Úferregion und den Randgebicten des freien Sees. - Z. Fisch. Deren Hilfswiss. 37: 637688 .

ORTH. R. J.. Ht. K. K. L. J. \& Montrans, v. J. (1984): Faunal communities in seagras bedn a revieu of the influence of plant structure and prey characteristics on predalor-pres relationships. - Estuaries 7: 339-350.

Piercf. C. L.. R tsml ssf. J. B. \& Leggeti. W. C. (1994): Litoral fish comnumities in Southem Quebec lakes: relationships with limnological and prey resource variables. - C:m. J. Fish. Aquat. Sci. 51: 1128-1138.

PIT(HI.k. T. J. \& H>RI. P. J. B. (1982): Fisheries ecology. - Croom Helm, London New York.

RadKL.. R. (1993): Lntersuchungen zur Nahrungswahl piscivorer Fische im Litoral des Bodensee, - Master Thesis. Universitäı Konstanz.

RöscH. R. \& S(HMID). W, (in press): Ruffe (Gymnocephalus cementas L.). newly introduced into Lake Constance: population dynamics and possible effects on whitefish. preliminary data. - Ann. Zool. Fenn. 33.

SAS (1988): SAS/STAT users's guide: version 6. Cary, NC: SAS Institute Inc.. North Carolina.

SAvINO. J. F. \& SIFIS. R. A. (1989): Behavioural interactions between fish predators and their prey: effects of plant density. - Anim. Behav. 37; 311-321.

Schlossr. I. J. (1987): The role of predation in age- and size-related habitat use by stream fishes. - Ecology 68: 651-659.

- (1982): Trophic structure. reproductive success, and growth rate of lishes in a natural and modificd headwater stream. - Can. J. Fish. Aquat. Sci. 39: 968--978. 
Scon . W. B. \& Crossmann. E. J. (1973): Freshwater fishes of Canada. - Fish. Res. Bd. Canada Bull. 184: $641-645$.

Vince, S., Vaith. a, I., Bar'ki's. N. \& Teal.. J. M. (1976): Predation by the aalt marsh killifish Fundulus heteroclitus (L.) in relation to prey size and habitat structure: consequences for prey distribution and abundance. - J. Exp. Mar. Biol. Ecol. 23: $255-266$.

Wfrner. E. E.. Gillitam. J. F. Hali, D. J. \& Mil mil barh. G. G. (1983): An experimental test of the effects of predation risk on habitat use in fish. - Ecology 64: $1540-1548$.

Werner. E. E.. Hall. D. J.. Laughlin, D. R., Wagner. D. J.. Witsmann. L. A. \& Funk. F. C. (1977): Habitat partitioning in a freshwater fish community. - J. Fish. Res. Board. Can. 34: 360-370.

We 2 Zel, R. G. (1983): Limnology. - Sounders College Publication. Philadelphia.

Submitted: 20 July 1996: accepted: 11 January 1997. 